\title{
В.М. Шеверьова
}

\section{ВПлив хронічного емоційного стресу на поведінку в тесті "відкритого поля" щурів із різним рівнем рухової активності}

\begin{abstract}
Досліди проводили на 41 щуреві (самиі, лінія Вістар) масою 180-220 г. Показано, щяо за умов тестування у "відкритому полі" тварини різнилися рівнем руховоі активності. Незалежно від локомоиії досліджувані групи щурів були неоднорідні за критерієм “емоційності" $i$ латентним періодом виходу з иентру “поля”. Тривалий нейрогенний стрес виявляв неоднозначний (модулювальний) вплив на поведінку тварин у тесті “відкритого поля”, яка залежала від їх вихідної активності. У низькоактивних щурів стресування в основному активізувало рухові та пошукові компоненти поведінки на тлі деякого зменшення актів дефекаиій. У середньоактивних тварин стресування збільшувало число стійок $і$ посилювало екскреторну функиію, а у високоактивних - зменшувало горизонтальні пересування та знижувало пороги реакиій на електрошкірне больове подразнення, сприяло підвищенню у иих щурів рівня “емоційності". Спрямованість змін часу виходу з иентру “поля” в кожній досліджуваній групі визначалася в основному його вихідними характеристиками $і$ по завершенні періоду стресування мала зворотну залежність. Висловлюється думка, щяо зміни поведінки тварин у тесті “відкритого поля" за відповідної інтенсивності стресуючих впливів могли бути зумовлені як нейроендокринними зрушеннями, так і стресорним ушкодженням мозкових структур.

Ключові слова: тест “відкритого поля”, рухова активність, хронічний емочійний стрес.
\end{abstract}

\section{ВСТУП}

Дослідження індивідуально-типологічних особливостей поведінки за умов екстремальних впливів нейрогенних чинників $\epsilon$ актуальним завданням експериментальної та клінічної нейрофізіології. Серед методів визначення типологічних властивостей поведінки щурів широке застосування знаходить тест "відкритого поля”, який вважається стресовим подразником для тварин [1, 11]. Це дає змогу виявити не тільки індивідуальну реакцію на аверсивні умови відкритого простору, але i на зміни функціонального стану щурів за умов несприятливої дії різноманітних агентів, у тому числі і нейрогенної природи. Дані літератури щодо ефектів стресорних впливів на поведінку у “відкритому полі"

(C) В.М. Шеверьова суперечливі, що може бути зумовлено як вибором моделі стресу, показників та режимів стресування, так і індивідуальними особливостями тварин. Урахування індивідуальної реакції на невротизуючі впливи має важливе значення при розробці заходів, спрямованих на попередження стресорних порушень та їх наслідків [17, 27, 29, 30]. Незважаючи на важливість цієї методики, багато питань, що стосуються інтерпретації характеристик поведінки в тесті “відкритого поля”, і дотепер залишаються предметом дискусії. Серед причин, що зумовлюють розбіжності, важливе місце займають генетичні фактори, умови досліду, а також використання авторами різних підходів у пошуку критеріїв індивідуальнотипологічних особливостей поведінки 
тварин за умов тестування. Існує думка [9], що рухова активність $є$ одним із основних чинників, який визначає різноманітні прояви адаптивної поведінки та стійкість до несприятливих умов навколишнього середовища. Хоча природа спонтанної локомоторної активності та їі фізіологічні механізми до цього часу вважаються не встановленими [12], різний рівень рухової активності пов'язують із обміном нейромедіаторів [10], гормонів [1, 3], енергетичними та генетичними факторами $[3,8]$, взаємовідносинами структур мозку [25], проявами внутрішніх властивостей індивідуума (відповідною потребою у русі) [12] тощо.

Мета нашої роботи - дослідити вплив хронічного нейрогенного стресу на поведінку у “відкритому полі" щурів з різною руховою активністю.

\section{МЕТОДИКА}

Досліди проведено на 41 щуреві (самці, лінія Вістар) масою 180-220 г. Для виявлення індивідуальних розбіжностей характеристик поведінки тварин використовували стандартну методику “відкритого поля" [5]. “Поле” являло собою ділянку (1 $\left.\mathbf{m}^{2}\right)$, яка була обмежена по периметру непрозорим бортом висотою 35 см і розділена на 25 рівних квадратів. Джерелом освітлення була лампа напругою 60 Вт, що встановлювали на висоті 1 м над центром “поля". Тестування у “відкритому полі" проводили у відносно звукоізольованій камері упродовж 5 хв. Реєстрували горизонтальну та вертикальну (з опорою і без опори на стінку) рухову активність (за числом перетнутих квадратів і стійок), “емоційність" (за числом актів дефекацій i уринацій), реакції умивання та інші види грумінгу (чищення, викушування шерсті та лапок, облизування, почісування), число виходів у центр “поля” (внутрішній i центральний квадрати), латентний період виходу 3 центру “поля” (центрального квадрата) на периферію (зовнішні квадрати) на початку тестування. 3 огляду на сезонні та добові зміни рухової активності, досліди проводили у весняно-літній період у ранкові години з 9.30 до 10.30 [12]. Пороги реакцій щурів на електрошкірне подразнення реєстрували в камері 3 електрифікованою підлогою. Стрес викликали електростимуляцією кінцівок щурів (тривалість 1 год) у цій самій камері. Використовували синусоїдальний струм частотою 50 Гц. Подразнення наносили за відповідною схемою (тривалість стимуляції та міжстимульного періоду - 10 с). Тривалість стресування 7-8 діб [30]. Параметри подразнення підбирали для кожної тварини індивідуально. Інтенсивність стимуляції помірно перевищувала поріг ноцицепції (про що судили за проявами поведінки). За показниками рухової активності та виходу в центр “поля” всі щури були поділені на 3 групи. До I групи ввійшли тварини 3 найнижчим рівнем рухливості (мінімальне та максимальне число перетнутих квадратів і стійок 2-23, низькоактивні, $\mathrm{n}=16$, які практично не виходили в центр “поля". При доборі щурів у II групу враховували початок виходу в центр “поля” (рухова активність цих тварин була вищою, ніж у щурів I групи), а також високий рівень переміщень по периферії без виходу в центр “поля”. Таким чином, у цю групу ввійшли тварини 3 проміжним рівнем рухової активності (мінімальне та максимальне число перетнутих квадратів і стійок 26-77, середньоактивні, $\mathrm{n=14)}$. У щурів III групи рухова активність була найвищою, всі тварини цієї групи виходили в центр “поля” (мінімальне та максимальне число перетнутих квадратів і стійок 84-141, високоактивні, $\mathrm{n}=11$ ). Незалежно від рухової активності, в кожній досліджуваній групі можна було виділити тварин із різними значеннями латентного періоду виходу 3 центру “поля”, а також “емоційних” (із дефекацією, уринацією) i “неемоційних".У III групі була найменша кількість щурів із високими показниками 
латентного періоду виходу із центру “поля” та ознаками “емоційності”, до того ж рухова активність у них була найвищою. Статистичне опрацювання результатів проводили 3 використанням критеріїв $\mathrm{t}$ Стьюдента і Т Вілкоксона (для вибірок, що відрізнялися від нормального розподілу). Коефіцієнти кореляції обчислювали за Спірменом (програма Primer of Biostatistics, Version 4.03).

\section{РЕЗУЛЬТАТИ ТА ЇХ ОБГОВОРЕННЯ}

Дослідження поведінки у “відкритому полі” виявило істотні відмінності між групами щурів за загальним числом перетнутих квадратів і стійок $(\mathrm{P}<0,01)$, числом перетнутих квадратів $(\mathrm{P}<0,01)$, загальним числом стійок з опорою і без опори на стінку $(\mathrm{P}<0,01)$ та окремими показниками стійок 3 опорою $(\mathrm{P}<0,05)$ і без опори $(\mathrm{P}<0,05)$. Середньоактивні та високоактивні тварини порівняно 3 низькоактивними істотно різнилися між собою за числом виходів у центр “поля” ( $<<0,02$ та $\mathrm{P}<0,001$ відповідно), а середньоактивні щури порівняно 3 низькоактивними - за латентним періодом виходу з центру “поля” (Р<0,02). Розбіжності між групами за показниками грумінгу, дефекацій та уринацій, порогів реакцій на електрошкірне подразнення були несуттєвими (рисунок). Показано, що пролонгований нейрогенний стрес усіх щурів істотно збільшував число стійок (вихідні

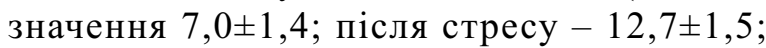
P <0,02) і більше ніж у 1,5 раза число виходів у центр “поля” й актів дефекації, а також знижував пороги реакцій тварин на електрошкірне подразнення (вихідні значення $25,1 \pm 0,9$; після стресу $-21,6 \pm 1,2$; $\mathrm{P}<0,05)$. Обчислення коефіцієнтів кореляції у вихідному стані і за умов стресу виявило тісний позитивний зв'язок між горизонтальною та вертикальною активністю $(\mathrm{r}=$ 0,686; $\mathrm{P}<0,001$ i r $=0,857 ; \mathrm{P}<0,001$ відповідно) та відсутність жорсткої зворотної залежності між руховою активністю (горизонтальною, вертикальною) і латентним періодом виходу щурів із центру "поля" $(\mathrm{r}=-0,273 ; \mathrm{P}>0,05$ i $\mathrm{r}=-0,310 ; \mathrm{P}>0,05$ відповідно). Тривале стресування неоднозначно впливало на поведінку у “відкритому полі” тварин, які різнилися рівнем рухової активності. Емоційний стрес істотно збільшував рухове збудження (горизонтальну та вертикальну активність, число виходів у центр “поля") в групі низькоактивних щурів (див. рис.). Проте тільки у половини (у 8) тварин цієї групи показники рухової активності могли сягати вихідного рівня середньо- та високоактивних щурів. $\mathrm{y}$ інших низькоактивних тварин зміни рухливості мали різне спрямування, проте загальне число горизонтальних переміщень і стійок у цих щурів залишалося в межах цієї групи. У деяких низькоактивних тварин поява або збільшення актів дефекації не залежали від рухової активності та спостерігалися як у щурів із ознаками гіперактивності, так і у тварин, які демонстрували незначні зміни рівня локомоції. Водночас у більшості “емоційних" щурів цієї групи фізіологічних відправлень по завершенні періоду стресування не було або число актів дефекацій і уринацій зменшувалося. У середньоактивних тварин число горизонтальних переміщень істотно не відрізнялося від вихідних показників. Для щурів цієї групи характерним було істотне збільшення загального числа стійок і стійок без опори на стінку та збільшення майже удвічі відвідувань центру “поля” (див. рис.). На відміну від тварин I групи, кількість “емоційних" щурів (із дефекацією та уринацією) в II групі збільшувалася (на 50 \%). У тварин III групи за умов стресу істотно знижувалася горизонтальна активність i зменшувалися відвідування центру “поля” (на 39,1 \%) без суттєвих змін показників вертикальної активності (див. рис.). У деяких щурів цієї групи, в тому числі у тварин із найвищим вихідним рівнем 

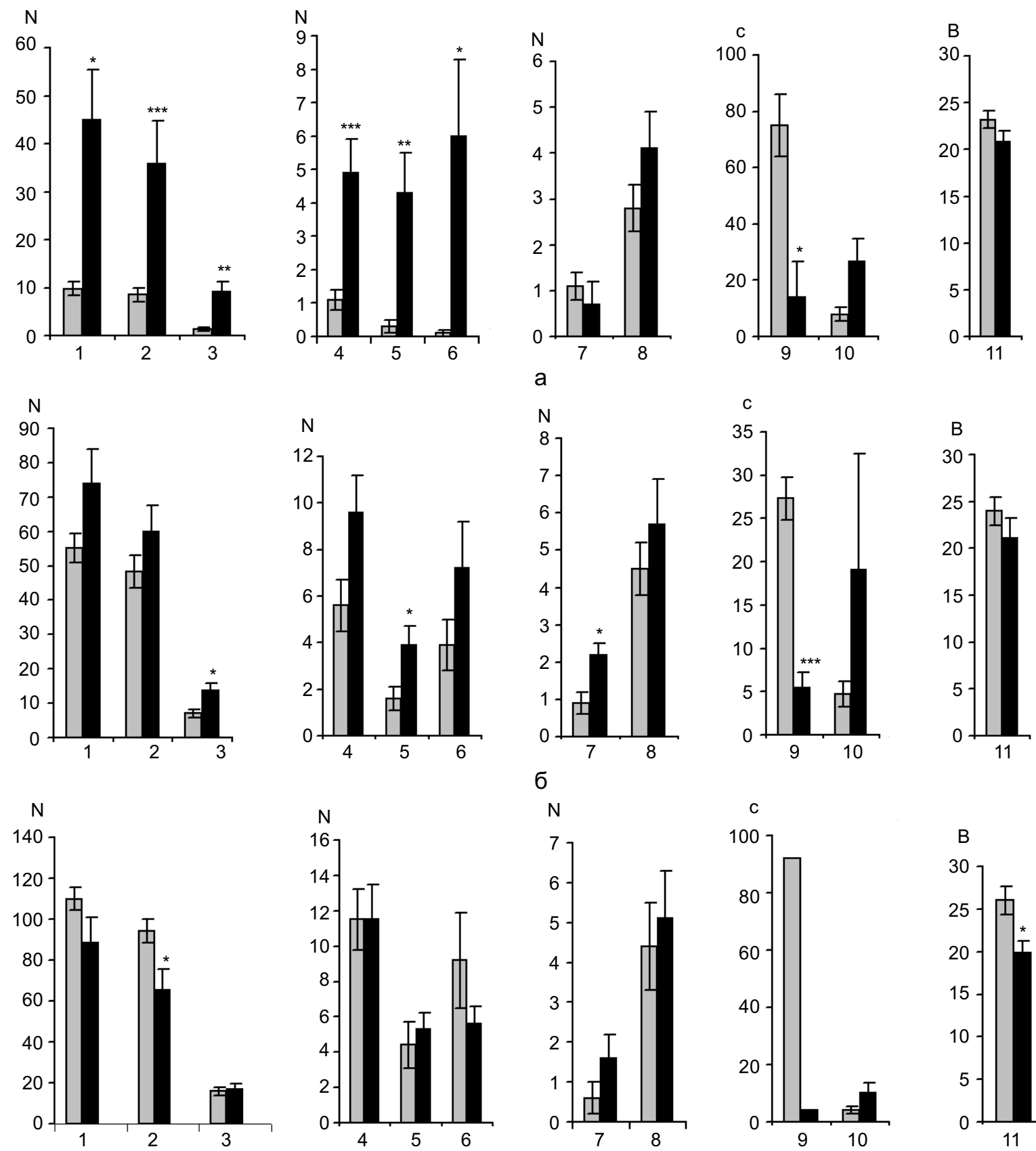

6
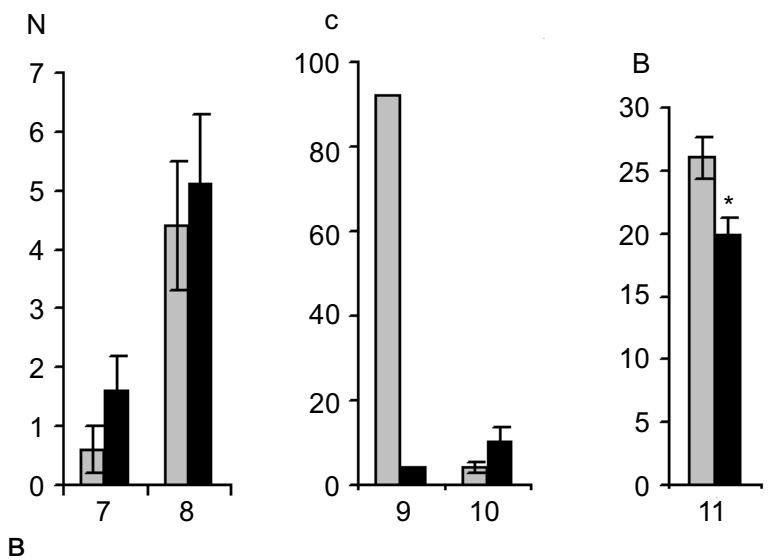

Динаміка поведінки в тесті “відкритого поля” щурів із різним рівнем рухової активності за умов хронічного емоційного стрессу: а - низькоактивні; б - середньоактивні; в - високоактивні; 1 - загальне число перетнутих квадратів і стійок; 2 - число перетнутих квадратів; 3 - загальне число стійок; 4 - число стійок із опорою, 5 - без опори на стінку; 6 - число виходів у центр “поля”; 7 - число актів дефекацій і уринацій; 8 - число реакцій грумінгу; 9 - латентний період виходу з центру “поля” у щурів із високими, 10 - низькими його вихідними показниками; 11 - пороги реакцій на електрошкірне подразнення; світлі стовбці-до початку стресу; темні - через 7-8 діб після стрессу.

$* \mathrm{P}<0,05 ; * * \mathrm{P}<0,02 ; * * * \mathrm{P}<0,001$ вірогідність відмінностей зі значеннями до стресу 
рухливості та “емоційності”, зменшення горизонтальних пересувань за умов стресу супроводжувалося рясною дефекацією або збільшенням числа болюсів. Інші щури цієї групи залишалися емоційно стабільними у “відкритому полі" і після завершення періоду стресування, проте у деяких із цих тварин число горизонтальних переміщень i стійок різко зменшувалося або щури знаходилися в стані рухової загальмованості. Кількісний аналіз “емоційності” в кожній досліджуваній групі показав, що за умов стресу число болюсів і уринацій у низькоактивних тварин знижувалося майже до вихідного рівня високоактивних щурів, тоді як у високоактивних спостерігався приріст їх показників (на 167 \%). За умов стресування екскреторна функція в тесті “відкритого поля” була найбільш виражена у середньоактивних тварин. Частота фізіологічних відправлень у цих щурів істотно підвищувалася і майже в 2,5 раза перевищувала вихідний рівень (див. рис.). Різною мірою виражений приріст реакцій грумінгу в усіх трьох групах (на 46, 26,7 i 15,9 \% відповідно) загалом супроводжувався скороченням тривалості умивань. Спрямованість змін латентного періоду виходу із центру “поля" в кожній досліджуваній групі визначалася в основному його вихідними показниками і по завершенні періоду стресування мала зворотну залежність. За умов високих вихідних характеристик часу виходу із центру “поля" його показники при стресі істотно знижувалися в усіх групах. У разі низьких вихідних значень латентного періоду виходу з центру “поля" ці показники підвищувалися у щурів усіх груп, проте найбільш вираженою ця тенденція була у середньо- та високоактивних тварин $(\mathrm{n}=7 ; \Delta=3 ; \mathrm{P}<0,05$ і $\mathrm{n}=9$; $\Delta=6 ; \mathrm{P}<0,05$ відповідно; див. рис.). Обчислення коефіцієнтів кореляції між часом виходу із центру “поля” та руховою активністю показало, що стресування значно посилювало зворотну залежність між цими показниками у щурів II та III груп, проте більш вираженими зміни були в середньоактивних тварин (вихідні значення - $\mathrm{r}=$ 0,$187 ; \mathrm{P}>0,05 ;$ після стресу $-\mathrm{r}=-0,596$; $\mathrm{P}<0,05)$. Істотне зниження порогів реакцій щурів на електрошкірне подразнення по завершенні періоду стресування спостерігалося лише в групі високоактивних тварин (див. рис.).

Таким чином, дослідження показали, що за умов тестування у “відкритому полі" щури різнилися рівнем рухової активності. Такий висновок узгоджується 3 літературними даними [14] і з концепцією [9], згідно з якою існує неоднорідність звичної рухової активності людини в різних вікових періодах, що дало змогу виділити три функціональні типи осіб (із низькою, середньою і високою руховою активністю) 3 властивими їм типологічними характеристиками. Вплив хронічного емоційного стресу на поведінку тварин у тесті “відкритого поля" значною мірою залежав від вихідного рівня їх рухової активності. У низькоактивних щурів нейрогенний стрес впливав переважно на рухові компоненти поведінки (підвищував горизонтальну активність, число стійок і виходів у центр “поля" на тлі деякого зменшення актів дефекації), знижував латентний період виходу із центру “поля” у тварин із високими вихідними його показниками. У середньоактивних щурів стресування істотно збільшувало число стійок і актів дефекації, а у високоактивних - знижувало число горизонтальних переміщень і пороги реакцій тварин на електрошкірне подразнення, посилювало екскреторну функцію, знижувало або підвищувало час виходу із центру “поля”. Такі зміни поведінки в тесті “відкритого поля” свідчили про підвищення емоційної реактивності у середньо- i високоактивних тварин. Вірогідним критерієм “емоційності", яка зазвичай відображає високий рівень негативного емоційного напруження, більшість авторів вважають дефекацію, інколи - дефекацію і латенцію $[10,11,23]$. Дані літератури щодо зв'язків 
рухової активності з “емоційністю” досить суперечливі $[11,23]$. Відсутність кореляції між рівнем локомоції та частотою дефекацій у тесті “відкритого поля” дало підставу деяким авторам вважати, що ці показники характеризують різні сторони функції ЦНС рухові та емоціональні [3]. Тобто серед активних і пасивних особин зустрічаються як “емоційні”, так і “неемоційні”. Зазвичай високу рухливість пов'язували з активністю норадренергічних і дофамінергічних, a низьку - холінергічних і серотонінергічних систем мозку $[11,28]$. Рівень "емоційності" позитивно корелював переважно 3 діяльністю холінергічних і негативно - норадренергічних систем мозку $[3,11]$. Низькоактивні щури характеризувалися малим вмістом норадреналіну та дофаміну i високим вмістом продуктів розпаду серотоніну (5-оксиіндолуксусної кислоти) у сенсомоторній корі та голубій плямі, а високоактивні - високим вмістом норадреналіну та дофаміну в голубій плямі та норадреналіну, дофаміну і діоксифенілуксусної кислоти - в сенсомоторній корі [10]. У активних тварин вміст метаболітів дофаміну в стріатумі та активність ферментів обміну медіаторів у сенсомоторній корі, хвостатому ядрі та n. accumbens були вищі, ніж у пасивних $[6,22]$. Проте деякі автори вважають, що ефективність функціонування ферментативних систем, які визначають енергозабезпечення клітин, добре збалансована у представників різних поведінкових типів [8]. У нормі в низькоактивних (“неемоційних") щурів вміст катехоламінів у сечі був менший, ніж у високоактивних [3], а вміст катехоламінів у крові низькоактивних і високоактивних менший, ніж у середньоактивних тварин [1]. Стресування підвищувало вміст адреналіну в сечі вегетативно реактивних i норадреналіну у вегетативно малореактивних щурів та адреналіну і норадреналіну у малоактивних тварин майже до вихідного вмісту катехоламінів високоактивних щурів [3]. Так само підвищувався вміст норадре- наліну у низькоактивних тварин за умов стресу в сенсомоторній корі та голубій плямі [10]. Очевидно, що підвищення рухового збудження у низькоактивних щурів без виражених ознак “емоційності" чи в супроводі уринацій і дефекацій за умов стресу в наших дослідах могло бути пов'язане як із фізіологічною мобілізацією організму, так і зростанням тривожності та емоційної нестабільності, що зазвичай супроводжувалися підвищенням у крові i сечі вмісту норадреналіну та адреналіну відповідно [1, 3, 38]. Високий рівень рухової активності за умов гострого емоційного стресу корелював зі збільшенням у корі та гіпокампі посередників стрес-відповідей, біологічних предикторів занепокоєння i/або депресії [36]. Підвищення локомоції за умов емоційного стресу пояснювали також участю в організації такої поведінки мезолімбічного дофаміну й опіоїдних систем [33]. Щури 3 низькою руховою та дослідницькою активністю, а також із високою частотою дефекацій і більшою латенцією, тобто з високим рівнем “емоційності”, характеризувалися низькою адаптацією, схильністю до виразок шлунка, ушкоджень сполучної тканини та ендотеліоцитів аорти [3, 10, 27]. У чутливих до стресу “емоційних" тварин (за показниками збільшення маси надниркових залоз, вираженої атрофії тимуса, високого рівня тривожності, рухового збудження тощо) спостерігали підвищений рівень вільнорадикального окиснення в мозку, печінці та міокарді до і після стресу та ультраструктурні зміни в мікроциркуляторному руслі гіпоталамуса і міокарда за умов стресу, підвищувалася активність тирозингідроксилази, що вказувало на посилений обмін катехоламінів у гіпоталамусі та стріатумі [4]. Водночас нечаста дефекація та низький вміст катехоламінів у крові активних і пасивних щурів [1], високий рівень рухових і пошукових реакцій та зниження “емоційності” у пасивних тварин за умов тривалої невротизації дали підставу 
деяким авторам зробити висновок про меншу чутливість цих щурів до дії стресуючих агентів порівняно з тваринами, які не сформували домінуючого типу поведінки [23]. Особливості окиснювального метаболізму у щурів із пасивним типом поведінки забезпечували цим тваринам (порівняно 3 середньоактивними та активними) середній ступінь стійкості і до гіпоксії, і до стресу [21]. 3 огляду на залежність рухливості в тесті “відкритого поля” від активності дофамінергічної системи, цікавим є той факт, що тривала, але помірна гіпоксія могла сприяти зменшенню негативних проявів хронічного дефіциту церебрального дофаміну [20]. Підвищення рухового збудження та скорочення тривалості грумінгу у “відкритому полі” після одноразової гострої гіпобаричної гіпоксії у щурів iз пасивним типом поведінки деякі автори пов'язували 3 гіпоксичним ушкодженням (дифузною загибеллю нейронів) гіпокампа і неокортекса, яке могло бути спричинене як гострим, так і хронічним стресом [25] i до якого максимально чутливі тварини 3 пасивним типом поведінки [14]. Відомо, що невротизація призводила до зниження локального кровотоку та ультраструктурних зрушень, характерних для гіпоксичних станів. За цих умов компенсаторне підвищення перекисного окиснення ліпідів порушувало структуру та функцію мембран [25]. Дослідження зони CA1 гіпокампа, яка найбільш чутлива до нестачі кисню та глюкози показало, що короткотривала аноксія-гіпоглікемія призводила до патологічних морфофункціональних змін, а довготривала - до загибелі нейронів [15]. Найбільш виражені дегенеративні зміни за умов “зоосоціального стресу” спостерігалися в гіпокампі [2], а значна роль у розвитку деструктивних змін у цій структурі при тривалому стресі належала кортикостероїдним гормонам [37]. Ушкодження гіпокампа призводило до збільшення всіх показників активності лише у 3-місячних щурів [24]. У дослідженнях Арушанян i співавт. [2] гіпокампектомія посилювала локомоцію та знижувала тривожність. Отже, морфофізіологічні зміни в новій корі та гіпокампі за умов довготривалого стресу могли порушувати їх специфічну функцію гальмівного впливу на активуючі системи мозку [24]. Не виключено, що за цих умов підвищення рівня рухового збудження і зниження рівня “емоційності” у низькоактивних тварин здійснювалися через вивільнення з-під гальмівноговпливу лімбічних утворень (септогіпокампальної системи) активувальних (ретикулярнонеокортикальних) систем мозку [25] або через ушкодження аферентних шляхів, які йшли від гіпоталамуса до лімбічних утворень мозку [31]. 3 огляду на глибокі зміни в біоелектричній активності лімбіконеокортикальних структур і емоційній сфері щурів за умов моделювання емоційних порушень [29, 30], особливості поведінки в тесті “відкритого поля" при довготривалому стресі у низькоактивних тварин могли бути наслідком морфофізіологічних зрушень у відповідних відділах нервової системи, що дало би підставу вважати цих щурів найбільш чутливими до емоційного стресу, проте це питання потребує окремого вивчення. Деякі автори чутливість до емоційного стресу намагалися прогнозувати за орієнтувально-дослідницькою поведінкою, за розподілом біогенних амінів у різних структурах мозку, вмістом у гіпоталамусі деяких олігопептидів тощо [8, $10,23,27]$. Існує думка [6], що оцінка будьякого поведінкового акту потребує комплексу біохімічних i, очевидно, морфофізіологічних показників 3 урахуванням “емоційності", рухової активності, а також інтенсивності та тривалості стресорних навантажень [8]. Окрім того вважають, що, зокрема, генетично зумовлена стійкість до стресорних ушкоджень $є$ не універсальною, а специфічною для різних систем організму, оскільки щури лінії Вістар, які більш стійкі до ушкоджень серцево-судинної системи, менш витривалі 
до стресорних ушкоджень шлунка та порушень патернів поведінки, ніж щури інших ліній (лінія Август) [19, 27]. Відомо, що хірургічне видалення гіпокампа та прилеглого неокортекса, а також посилення адренергічних впливів сприяло скороченню тривалості грумінгу [13]. Збільшення частоти грумінгу за умов стресу розглядали як один із компонентів активно-оборонної [26] або як показник “зміщеної” поведінки [1]. Отже, особливості поведінки низькоактивних тварин у тесті “відкритого поля” за умов тривалих стресових впливів (збільшення локомоції, стійок, виходів у центр “поля" на тлі зменшення актів дефекації) могли бути зумовлені як перебудовами в системах нейромедіаторного та гормонального контролю поведінки, так і стресорним ушкодженням мозкових структур.

Відомо, що особини з середнім рівнем рухової активності відрізнялися значною неоднорідністю популяції, зокрема, за стійкістю до гіпоксії [14] або розглядалися як тварини, котрі найбільш чутливі до стресу, на відміну від щурів крайніх типів поведінки [1, 21, 23]. Матрицею збудженого стану зазвичай вважали локомоцію та стійки $з$ опорою на стінку. Вертикальну активність розглядали також як спробу до втечі, як один із прикладів оборонної мотивації. Часті переміщення деяких тварин цієї групи по периферії з униканням центру “поля” (острах відкритого простору) у вихідному стані, виражена тенденція до підвищення латентного періоду виходу із центру “поля" у щурів із низькими вихідними його показниками за умов стресу та збільшення стійок або стійок і актів дефекації, а також збільшення актів дефекації на тлі зниження або підвищення рухового збудження вказували на розвиток у них гострого емоційно-стресового стану (реакції страху, “емоційної тривожності”, рухового неспокою) та посилене реагування щурів на більш слабкий подразник (“відкрите поле”) порівняно 3 передуючим йому тривалим періодом стресування [1, 16, 23].
Таку поведінку зазвичай вважали характерною ознакою розвитку слабкості нервових процесів [1, 23], що вказувало на понижену резистентність тварин до довготривалого стресу.

Показано, що щури з високою вихідною руховою та дослідницькою активністю, високим порогом больової чутливості, коротким періодом латенції і низькими темпами дефекації були більш стійкими до стресу $[10,17,23,27]$. Відомо також, що норадредренергічні системи мозку, особливо гіпоталамуса, залучають у механізми стресорних реакцій симпатоадреналову систему, надмірне напруження якої призводило до патологічних змін вищої нервової діяльності та формуванню захисних (оборонних) типів поведінки [29, 30, 34, 35]. Очевидно, що істотне зниження горизонтальних переміщень, які зазвичай пов'язували $з$ активно-оборонною поведінкою, та виражена у більшості високоактивних щурів тенденція до підвищення латентного періоду виходу із центру “поля" за умов ситуації, яка унеможливлювала уникнення довготривалого стресу, могли бути наслідком перенапруження та зриву “вищої нервової діяльності” [3]. Зниження в цілому рухової активності та збільшення актів дефекації та вмісту катехоламінів у крові за умов впливу різноманітних стресуючих агентів [1, 38] вказували на посилення у тварин негативної реакції на стресуючий подразник (“відкрите поле”). У високоактивних "емоційних" щурів із підвищеним вихідним вмістом адреналіну в сечі нанесення електрошкірного подразнення могло спричинювати різке зменшення вмісту гормону, що свідчило про зниження у цих тварин тонусу адренергічних механізмів [3]. Ослаблення вказаних механізмів призводило до зменшення загального та психічного тонусу організму і розвитку рухової загальмованості [1, 23, 32]. Порушення катехоламінергічної іннервації переднього мозку через уведення 6оксидофаміну збільшувало латентний 
період виходу щурів із центру “поля” [18], знижувало рухову та пошукову активність і підвищувало число болюсів у групі тварин, стійких до акустичного стресу [7]. Головним чинником у розвитку дефіциту поведінки деякі автори вважали зниження вмісту дофаміну [28]. Зменшення вмісту дофаміну після іммобілізаційного стресу відмічали в голубій плямі та сенсомоторній корі щурів лінії Вістар із високим вихідним рівнем рухової активності [10]. Водночас активація дофамінергічного субстрату стріатума полегшувала емоційні реакції негативного характеру та агресивність [4]. Зниження рухливості в тесті “відкритого поля", ймовірно, спричинялося також гострою гіпоксією, яка вважається одним iз потужних стресових факторів [16]. У гіпокампі нетривала киснево-глюкозна депривація індукувала довготривалу потенціацію синаптичної передачі, що в разі пролонгованої дії призводило до гіперзбудження [15]. Відомо, що за умов довгочасного емоційного стресу високий рівень негативного емоційного напруження та перенапруження супроводжувався розвитком у гіпокампі гіперсинхронного ритму або стійкої депресії біопотенціалів [29, 30], а надмірна активація цієї структури призводила до дизритмії та різкого зниження нічної рухливості тварин [2]. Зниження горизонтальних переміщень поряд із тенденцією до підвищення латентного періоду виходу із центру “поля”, зниження порогів реакцій на електрошкірне больове подразнення та збільшення у деяких високоактивних щурів вегетативної реактивності в тесті “відкритого поля" за умов довготривалої стресової ситуації в наших дослідах вказували на початок переходу цих тварин до пасивно-оборонного типу поведінки та про зміну їх нейромедіаторного і гормонального балансу. Свідченням дещо більшої стійкості цих тварин до довготривалого стресу в наших дослідах (переважно за рахунок емоційно стабільних), очевидно, слід вважати меншу вираженість післястресорних змін поведінки у тесті “відкритого поля”. Разом 3 тим $з$ огляду на дані літератури та результати наших досліджень, ймовірно, що перебудови в системах нейромедіаторної та гуморально-гормональної регуляції, а також морфофізіологічні зміни в структурах мозку щурів із різними індивідуально-типологічними характеристиками за умов моделювання емоційних порушень [29, 30] призводили до змін у взаємовідносинах різних відділів ЦНС та утворень мозку і визначали симптоматику психоневрологічних і соматовегетативних зрушень, що знаходило своє відображення в різних проявах індивідуальної поведінки тварин у тесті “відкритого поля" [25].

Наші результати узгоджуються 3 роботами [12] щодо існування тісного позитивного зв'язку між горизонтальною та вертикальною активністю в тесті “відкритого поля” за умов і “безстресової”, i ”стресової” ситуації. 3 одного боку, відсутність тісного зворотного зв'язку між руховою активністю і часом виходу щурів із центру “поля" за результатами сумісного дослідження всіх груп незалежно від умов досліду (вихідного стану, стресу), а 3 іншого наявність цих зв'язків у деяких тварин за умов стресу, свідчили про існування відносної незалежності між вказаними характеристиками поведінки.

Отже, тестовані у “відкритому полі" щури різнилися рівнем рухової активності. Незалежно від локомоції всі тварини якоюсь мірою були неоднорідні за критеріями “емоційності" і латентного періоду виходу із центру “поля”. Незалежно від умов досліду (вихідного стану, стресу) тестування у “відкритому полі” виявило вірогідний позитивний зв' язок між горизонтальною та вертикальною активністю і відсутність жорсткої зворотної залежності між руховою активністю (горизонтальною, вертикальною) та латентним періодом виходу щурів iз центру “поля”. Хронічний нейрогенний стрес виявляв неоднозначний (модулювальний) вплив на поведінку тварин у тесті 
“відкритого поля”, залежну від їх вихідної рухової активності. За умов довготривалої стресової ситуації у низькоактивних щурів загалом активізувалися рухові та пошукові компоненти поведінки (підвищувалася горизонтальна та вертикальна активність, збільшувалося число виходів у центр “поля”) на тлі деякого зменшення актів дефекації. Тривалий стрес збільшував число стійок і актів дефекації у середньоактивних тварин і знижував горизонтальні переміщення та пороги реакцій на електрошкірне подразнення у високоактивних щурів разом із зміщенням у них вегетативного балансу в бік посилення екскреторної функції. Спрямованість змін латентного періоду виходу 3 центру “поля" в кожній досліджуваній групі визначалася загалом його вихідними показниками і на піку дії стресу мала зворотну залежність. 3 огляду на дані літератури та результати власних досліджень, можна припустити, що зміни характеристик поведінки щурів у тесті “відкритого поля” за відповідної інтенсивності стресуючих впливів могли бути зумовлені як нейроендокринними зрушеннями, так і стресорним ушкодженням мозкових структур.

\section{В.М. Шеверева}

\section{ВЛИЯНИЕ ХРОНИЧЕСКОГО ЭМОЦИОНАЛЬНОГО СТРЕССА НА ПОВЕДЕНИЕ В ТЕСТЕ “ОТКРЫТОГО ПОЛЯ” КРЫС С РАЗНЫМ УРОВНЕМ ДВИГАТЕЛЬНОЙ АКТИВНОСТИ}

Опыты проводили на 41 животном (крысы-самцы, линия Вистар) массой 180- 220 г. Показано, что тестируемые в “открытом поле” животные различались уровнем двигательной активности. Независимо от уровня локомоции, исследуемые группы крыс были неоднородны по критерию “эмоциональности” и латентному периоду выхода с центра “поля”. Длительный нейрогенный стресс оказывал неоднозначное (модулирующее) влияние на поведение животных в тесте “открытого поля”, зависимое от их исходного уровня активности. У низкоактивных крыс стрессирование в основном активизировало двигательнопоисковые компоненты поведения на фоне некоторого уменьшения актов дефекации. У среднеактивных животных стрессирование увеличивало число стоек и усиливало экскреторную функцию, а у высокоактивных - уменьшало горизонтальные перемещения и снижало пороги реакций на электрокожное раздражение, способствовало повышению у этих крыс уровня “эмоциональности”. Направленность изменений времени выхода с центра “поля” в каждой тестируемой группе определялась в основном его исходными характеристиками и на пике действия стресса имела обратную зависимость. Предполагается, что изменения поведения животных в тесте “открытого поля" при соответствующих интенсивностях стрессирующих воздействий могли быть обусловлены как нейроэндокринными сдвигами, так и стрессорным повреждением мозговых структур.

Ключевые слова: тест “открытого поля”, двигательная активность, хронический эмоциональный стрес.

\section{V.M. Shevereva}

\section{INFLUENCE OF CHRONICAL EMOTIONAL STRESS ON THE BEHAVIOUR IN "OPEN FIELD” OF RETS WITH DIFFERENT LEVEL OF MOTIONAL ACTIVITY}

Experiments were carried out on 41 Wistar mail rats with body weight of $180-200 \mathrm{~g}$. It was shown that in 'open field' the rats differed in the level of motional activity. Independently from level of locomotion investigated groups of rats were dissimilar at the criterions for "emotionality" and latent period of go out from the centr of "field". Prolonged neurogen stress rendered various (modulating) influence on the behaviour of the rats in 'open field' that was depended from their start level of activity. In the lowactive rats stress in the main activated the motional and searching components of behaviour against a background of some decrease of the acts of defecation. In the meanactive rats stress increased the freguency of rearing and strengthened excretion function and in the highactive of rats stress reduced the guantity of horizontal moving and lowered the thresholds of reactions of rats on the skin electrical stimulation, facilitated increase in these of rats the level of "emotionality". Direction of changes of the time go out from the centr of "field" in each tested group basically depended by its start indexes and on peak of stress action had reverse dependence. It is supposed that changes of behaviour of rats in the "open field" under corresponding intensity of stress may be coused as by neuroendokrine changes as by stress damage of brain structures.

Key words: "open field" test, motional activity, chronical emotional stress.

Research Institute of Biology, V.N. Karazin Kharkov National University

\section{СПИСОК ЛІТЕРАТУРИ}

1. Айрапетянц М.Г., Хоничева И.М., Мехедова А.Я. Реакции на умеренные функциональные нагрузки 
у крыс с индивидуальными особенностями поведения // Журн. высш. нерв. деятельности. - 1980. 30, вып. 5. - С. 994-1062.

2. Арушанян Э.Б, Бейер Э.В. Место гиппокампа в биоритмологической организации поведения // Успехи физиол. наук. - 2001. - 32, № 1. - С. 79-95.

3. Бенешова О. Генетически обусловленная изменчивость поведения у крыс и ее биохимические корреляты // Журн. высш. нерв. деятельности. 1978. - 28, вып. 2. - С. 314-321.

4. Бондаренко Н. А., Девяткина Т.А., Воскресенский О.Н. Влияние хронического эмоционального стресса на состояние перекисного окисления липидов в тканях и крови эмоциональных и неэмоциональных крыс // Бюл. эксперим. биологии и медицины. - 1995. 100, № 7. - C. 12-14.

5. Буреш Я., Бурешова О., Хьюстон П. Методики и основные эксперименты по изучению мозга и поведения. - М.:Высш. шк. - 1991. - 299 с.

6. Герштейн Л.М., Камышева А.С., Чеботарева Т.Л. Морфохимическая характеристика мозга крыс линии Вистар, различающихся по локомоторной активности в открытом поле // Журн. высш. нерв. деятельности. - 1991. - 41, вып. 2. - С. 300-304.

7. Гасанов Г.Г., Исмайлова Х.Ю., Громова Е.А. Роль катехоламинергической иннервации фронтальной области неокортекса в регуляции поведения крыс с различной устойчивостью к акустическому стрессу // Там же. - 1995. - 45, вып. 5. - С. 1007-1013.

8. Гуляева Н.В., Степанычев М.Ю. Биохимические корреляты индивидуально-типологических особенностей поведения крыс // Там же. - 1997, вып. 2. С. $329-338$.

9. Колпаков В.В., Беспалова Т.В., Брагина А.В. Концепция типологической вариабельности физиологической индивидуальности. Сообщение 1 . Внутрипопуляционное разнообразие привычной двигательной активности человека и ее типовая оценка // Физиология человека. - 2008. - 34, № 4. C. 121-132.

10. Коплик Е.В., Салиева Р.М., Горбунова А.В. Тест открытого поля как прогностический критерий к эмоциональному стрессу у крыс линии Вистар // Журн. высш. нерв. деятельности. - 1995. - 45, № 4. С. 775-781.

11. Кулагин Д.А., Болондинский В.К. Нейрохимические аспекты эмоциональной реактивности и двигательной активности крыс в новой обстановке // Успехи физиол. наук. - 1986. - 17, № 1. - С. 92-108.

12. Куликов В.П. Индивидуальные особенности спонтанной локомоторной активности и адаптивное поведение крыс // Журн. высш. нерв. деятельности. 1990. - 40, вып. 1. - С. 85-92.

13. Лепехина Л.М. Влияние резерпина на параметры груминга крыс // Бюл. эксперим. биологии и медицины. - 1993. - 115, № 1. - С. 10-11.
14. Ливанова Л.М., Айрапетянц М.Г., Германова Э.Л. Долгосрочное влияние однократной острой гипоксии на поведение крыс с разными типологическими особенностями // Журн. высш. нерв. деятельности. 1993. - 43, вып. 1. - С. 157-164.

15. Лушнікова І. В. Морфологічна пластичність клітин зони CA1 гіпокампа in vitro в умовах короткотривалої аноксії-гіпоглікемії та подальшої реоксигенації // Фізіол. журн. - 2009. - 55, № 3. - С. 109117.

16. Новиков В.Е., Арбаева М.В., Парфенов Э.А. Влияние антигипоксанта Q226 на поведение мышей в “открытом поле” // Психофармакология и биол. наркология. - 2005 . - 5, вып. 3. - С. 979-983.

17. Петров В.И., Григорьев И.А., Афименко В.Л. Прогнозирование устойчивости крыс к эмоциональному стрессу // Журн. высш. нерв. деятельности. - 1996. - 46, вып. 6. - С. 1119-1121.

18. Подклетнова И.М., Алхо Х.Е. Повреждение катехоламинергической системы обуславливает замедление формирования ранних поведенческих реакций у крыс // Там же. - 1995. - 45, вып. 5. С. 1023-1027.

19. Пшенникова М.Г., Бондаренко Н.А., Шимкович М.В. Различия в поведении и устойчивости к язвенному поражению желудка при стрессе у крыс линии Август и Вистар, адаптированных и неадаптированных к гипоксии // Бюл. эксперим. биологии и медицины. - 1999. - 128, № 12. - С. 638-641.

20. Сагач В.Ф., Базілюк О.В., Олешко М.М. Система оксиду азоту за умов хронічного дефіциту церебрального дофаміну та гіпоксії // Фізіол. журн. 1999. - 45, № 1-2. - С. 16-25.

21. Саркисова К.Ю., Коломейцева И.А. Индивидуальные различия в реакциях на острый стресс, связанные с типом поведения. Устойчивость (предрасположенность) к нарушениям поведения и сна // Бюл. эксперим. биологии и медицины. - 1993. 116, № 8. - С. 130-132.

22. Саульская Н.Б. Влияние невротизации на метаболизм дофамина мозга крыс с различной активностью в тесте “открытое поле” // Физиол. журн. им. И.М. Сеченова. - 1989. - 75, № 3. - С. 397-400.

23. Семагин В.Н., Зухарь А.В., Куликов М.А. Тип нервной системы, стрессоустойчивость и репродуктивная функция. - М.: Наука, 1988. - 133 с.

24. Семенова Т.П. Возрастные особенности адаптивного поведения гиппокампэктомированных крыс. - В кн.: Механизмы адаптивного поведения. - Л.: Наука, 1986. - C. 54-57.

25. Симонов П.В. Мотивированный мозг. - М.: Наука, 1987. $-266 \mathrm{c}$.

26. Стрекалова Т.В. Изменение оборонительной реакции у крыс под влиянием пептида, вызывающего дельта-сон // Журн. высш. нерв. деятельности. - 1995. - 45, вып. 3. - С. 593-595. 
27. Судаков К.В. Индивидуальность эмоционального стресса // Общие вопр. неврологии и психиатрии. 2005. - 105, № 2. - C. 4-12.

28. Шаповалова К.Б., Горбачевская А.И., Саульская Н.Б. Структурная организация и нейрохимические механизмы участия прилежащего ядра во взаимодействии лимбической и моторной систем и в регуляции двигательного поведения // Журн. высш. нерв. деятельности. - 1992. - 42, вып. 2. - С. 226276.

29. Шеверева В.М. Особенности формирования и обратимости эмоциональных нарушений у крыс при нейрогенном стрессе // Нейрофизиология / Neurophysiology. - 2003. - 35, № 2. - C. 147-158.

30. Шеверьова В.М. Нейрофізіологічні ефекти $\beta$-блокатора обзидану за умов моделювання емоційного стресу // Фізіол. журн. - 1997. - 43, № 1-2. C. $31-39$.

31. Ширяева Н.В., Вайдо А.И., Лопатина Н.Г. Влияние невротизации спустя длительные сроки после ее окончания на поведение крыс, различающихся по возбудимости нервной системы // Журн. высш. нерв. деятельности. - 1996. - 46, вып. 1. - С. 157-162.

32. Berman R.M, Narasimhan M., Miller H.L, Anand A. Transient depressive relapse induced by catecholamine depletion: potential phenotypic vulnerability marker? // Arch. Gen. Psychiatry. - 1999. - 56, № 5. - P. 395-440.

33. Buisman-Pijlman Femke T.A., Herremans A.H.J., Van De Kieft J., Kruse C.G., Van Ree J.M. Behavioural changes after different stress paradigms: Prepulse inhibition increased after physical but not emotional stress // Europ. Neuropsychopharmacol. - 2003. - 13, № 5. - P. 369-380.

34. Chrousos G.P., Gold P.W. The concepts of stress system disordes: overview of behavioral and physical homeostasis // J. Amer. Med. Asoc. - 1992. - 267. P. 1244-1252.

35. Craig W. Berridge. Noradrenergic modulation of arousal // Brain Res. Rev. - 2008. - 58, № 1. - P. 1-17.

36. Huanhuan Li, Wenjuan Lin, Junfa Li. The effects of acute emotional stressor on behavior and phosphorylation levels of neurogranin in rats // Acta Psychol. Sinica. - 2006. - 38, № 4. - P. 576-582.

37. Sapolsky R. Glucocorticoids, hippocampal damage and glutamatergic synapse // Prog. Brain Res. - 1999. - 86. P. 13-23.

38. Weyersa Peter, Bowerd David B., Vogelb Wolfgang H. Relationships of plasma catecholamines to open-field behavior after inescapable shock // Neuropsychobiol. 1989. - 22, № 2. - P. 108-116. 